\title{
「しむざらめ雪地域」の気候条件の再検討による 日本の積雪地域の質的特徴を表す新しい気候図
}

\author{
石坂 雅 昭 ${ }^{1)}$
}

\begin{abstract}
要旨
日本の積雪地域の積雪の質的特徵に基づく気候区分の一つである「し屯ざらめ雪地域」について, その気候的な意味をより明確にするため, 定義及び区分条件の再検討を行った。 そのため, 日本の積 雪地域のうち寒冷で相対的に積雪の少ない気象官署 21 地点の 1,2 月の気象デー夕から, 平年值期間 である 1971 2000 年の間に, 何冬期「しもざら雪地域」とみなせるようなしもざらめ雪の著しい発達 が見られたかを推定し, 区分条件との関係を調べた。 その結果, 平年值算定期間である 30 年間にしも ざらめ雪が著しく発達したと推定される年数の割合で「しもざらめ雪地域」を気候的かつ定量的に定 義することができること，対応する区分条件はその地域の気候的な雪中温度勾配を反映したあのであ ることなどがわかった。 そして, 上記で得られた新たな条件とその他の気候区の条件とを合わせ, 最 新のメッシュ気候值 2000 に適用して，積雪の質的特徵を表す新しい気候図を作成した.
\end{abstract}

キーワード : 積雪, しもざらめ雪, 気候区分, メッシュ気候值

Key words: snow cover, depth hoar, climatic division, mesh climatic data

\section{1. はじめに}

表題に掲げた「しもざらめ雪地域」は，筆者が 先に日本の積雪地域を厳冬期の積雪の質的特徵に 基づいて区分した気候区分概念の一つである（石 坂, 1995・1996). その名の示す通り, 積雪層内に 発達する「しもざらめ雪」が厳冬期の積雪を特徵 ゔける積雪地域を指している。このように広域の 積雪分布からしもざらめ雪が発達する地域を区分 したのは，秋田谷・遠藤 $(1980,1982)$ による北 海道の積雪分布の研究である. 彼らは数年間の調 査から，しもざらめ雪が発達する地域は, 積雪層 全体の硬度が小さく, しもざらめ雪が充分に発達 した厳冬期末の積雪の平均ラム硬度が一定の值よ り小さい地域として抽出できることを見出した. また，それにはその地域の積雪堆積時の気象環境 が反映していると考え, 先の平均ラム硬度と気温 と積雪深を結びつける経験式を提案し, 直接ラム

1）防災科学技術研究所雪水防災研究センター 于940-0821 長岡市栖吉町前山 187-16
硬度を測らなくても，気象要素からしもざらめ雪 の発達を推定できることを示した。

筆者の気候区分はその推定式の变数を気候值に 置き換えたものであった. その結果, 北海道の道 東, 岩手県の北上盆地, 長野の佐久盆地など, こ れまでの観測とも合う分布が得られ, 気候值で置 き換えたものでも，日本の「しもざらめ雪地域」 をよく表現できていることがわかった（石坂, 1995).しかし, 道東では, 秋田谷・遠藤（1982） などの観測結果と比べて，その領域はやや狭く， 区分条件がかなり限定的, すなわち厳しい方に設 定されていることがわかり，条件の緩和について も検討された（石坂，1996）.

条件が厳しい側になるのは，秋田谷・遠藤 （1980，1982）では，積雪深に月平均積雪が使われ ているのに対して, 気候值 (平年值) には平均積 雪はなく, 月最深積雪を使わざるを得なかったこ とに起因している，秋田谷・遠藤の式は，気温の 絶対值を積雪深で除した值, すなわち平均的な積 
雪の温度勾配が大きいほどしもざらめ雪が発達し 易いことを反映しているが，平均積雪と最深積雪 では一般に後者の方が大きいので，最深積雪を使 うと温度勾配が小さく算出され，その地点が「し あざらめ雪地域」となりにくいという事情を反映 している.

そこで前に述べた検討では，道東の観測結果と 比較しながら条件の緩和について議論したが，各 年の観測結果はあくまでもその冬の気象的な特徴 を反映したものであって，どの年の観測結果と比 べるのが妥当かという点で恣意性が残ることは避 けられず，明確性に欠けた（石坂，1996；Ishizaka， 1998）。すなわち，「しむざらめ雪地域」がどのよう な地域なのか，その発生頻度が考慮されていない ため，定量的に明瞭でないという問題点があった。

そこで，本稿では「しもざらめ雪地域」の区分 条件を再検討し，気候的な定義を定量的に示すと ともに，それに対応した新たな区分条件を提示す る.そして，新しく得られた「しもざらめ雪地域」 の気候条件とその他の区分とを合わせてメッシュ 気候値 2000（気象庁，2002）に適用して，これま で古いメッシュ気候值（気象庁，1996）で作成さ れていた積雪地域の厳冬期の積雪の質的な特徵を 表す気候区分図を更新することにした。

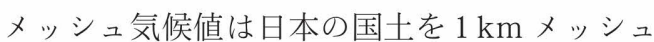
の区画に分けて，各区画に対応づけて気温，降水 量，積雪，日射量などの気候值が，気象官署や地 域気象観測点（アメダス）の観測值から地形因子 を考慮して推定され求められている。観測点の少 ない山地などでの誤差は少なくないものの，現状 では未観測点を含む日本全体の国土を覆う均質で 一定の精度を持ったデータだと考えられる。た だ，先に発表した区分図（石坂，1995）では，旧 メッシュ気候值（気象庁，1996）を用いたので， その中には日本の国土うち雪の少ない，関東，東 海, 紀伊半島, 四国, 九州の積雪の気候值は含ま れず，それら地域を除外したあのであった。しか し，メッシュ気候值 2000（気象庁，2002）では, 一部島嶼を除きほぼ全国の積雪データがそろった ので，ここではじめて日本全国の積雪地域全域を カバーして，かつ「しもざらめ雪地域」の気候的 な条件を明瞭にした積雪の質の気候図が作成され たことになる。
なお，積雪深の単位については $\mathrm{cm}$ の単位を用 いた。 多くの気象資料で慣用的に用いられている こと，またここで頻繁に使う秋田谷・遠藤 (1980, 1982）の式と単位をそろえ，形を変えずに使うこ とを考慮したからである。

\section{2. 秋田谷・遠藤の式とこれまでの「しもざ らめ雪地域」の気候値条件について}

秋田谷・遠藤（1982）は北海道の積雪の広域調 査から，しむざらめ雪が発達する地域は 2 月末の 平均ラム硬度 $R_{\mathrm{av}}(\mathrm{kg})$ が $8 \mathrm{~kg}$ より小さくなる地 域であること，その平均ラム硬度は 1,2 月の月平 均気温 $T\left({ }^{\circ} \mathrm{C}\right)$ と同じ期間の平均積雪 $H_{1}(\mathrm{~cm})$, そして 2 月末の積雪深 $H_{2}(\mathrm{~cm})$ で表される次の 式で関連づけられることを示した。彼らによるし もざらめ雪が発達するための条件式は,

$$
R_{\mathrm{av}}=0.339\left(H_{1} /|T|\right)^{1.21} H_{2}^{0.21}
$$

で表される $R_{\mathrm{av}}$ が，

$$
R_{\mathrm{av}}<8(\mathrm{~kg})
$$

というものである。ただし，Tは負の場合に限定 している。

筆者の提案した「しもざらめ雪地域」は上記の 条件のうち式(1)の各变数を気候值で置き換えて, 気候的な意味での「しもざらめ雪地域」を定義し たものである.ただし，Tには 1,2 月の月平均気 温の気候值（平年值）を平均したものを適用した が，前節で述べたように平年值には平均積雪はな いので， $H_{1}$ には $1 ， 2$ 月で平均した月最深積雪を 用いた。さらに, 式(1)の 2 月末の積雪深屯気候值 には存在しないので, 2 月と 3 月の月最深積雪の 平均に置き換えて上記の関係を利用した。そし て, 気温の条件は 1 月の月平均気温が $-1^{\circ} \mathrm{C} よ り$ 寒い地域とした。なぜなら，しもざらめ雪は厳冬 期に積雪がほぼ乾いた状態で推移する地域に限ら れるためである（石坂，1995）

式(1)の $H_{1} /|T|$ は 1,2 月の平均的な積雪の温 度勾配の逆数を表している，温度勾配が大きくな るとこの值は小さくなり (2)の条件を満たし易くな る。そこで，平均積雪ではなく月最深積雪を用い 
ると，一般的に後者の方が大きい值になるので， 先の温度勾配の逆数む, また $H_{2}$ に対応する部分む 大きめに算出さ机，条件式(2)を満たしにくくな る。これが前節でも述べた気候区分が限定的，す なわち厳しい側になることの大きな要因である。

したがって，条件を緩和することは，例えば式 (2)で $R_{\mathrm{av}}<9(\mathrm{~kg})$ の上うに， $R_{\mathrm{av}}$ が大きい地点屯 「しむざらめ雪地域」に含めていくことに対応し， 実際先の緩和に関する検討もそのような観点から 行われた（石坂, 1996 ; Ishizaka, 1998)。ここで あ同様な観点から緩和の検討に入るが，その前 に，これまでの研究から式(1)は， $H_{2}$ を含まない 1, 2 月の值だけで表すことができることがわかっ ているので，まずそ机しいて述へ，条件の緩和 に関する議論は，置き換えた後のより簡便な表現 による条件式において行うことにする。

\section{3. $1 ， 2$ 月の気候値のみを使った条件への 置き換え}

条件の式が 1,2 月の気温と積雪に関係する要 素からだけで表されることについては，既に旧 メッシュ気候值を用いて（石坂，1996；Ishizaka， 1998），また最近では新しいメッシュ気候值 2000 を用いて（石坂，2006b）述べてきたので繰り返し になるが，条件緩和の手法にも関わるので改めて 一連の結果を述べることにする。

前節の式 (1)，(2) の区分条件を気候值に置き換 えてメッシュ気候值 2000 に適用すると, 積雪地 域の中から「し屯ざらめ雪地域」の条件に適合す る地点（メッシュ）を抽出することができる。た だし，ここでは積雪地域として，冬期いずれかの 月の月最深積雪が $10 \mathrm{~cm}$ 以上である地点を対象 にしている。このようにして求めた地点は 37377 メッシュで，それらの地点の 1,2 月の值を平均し た月最深積雪と月平均気温の関係を表したのが図 1 である.この図を見ると,「しあざめ雪地域」が, やや上に凸の曲線的な境界より下にしかないこと がわかる。気温で決まる積雪の上限より積雪が多 い之積雪内の温度勾配が小さいということを反映 しているわけである。この境界が得られれば， 1 , 2 月の積雪と気温との関係のみから「しもざめ雪 地域」とその他の地域とを区分する条件が得られ ることがわかる。

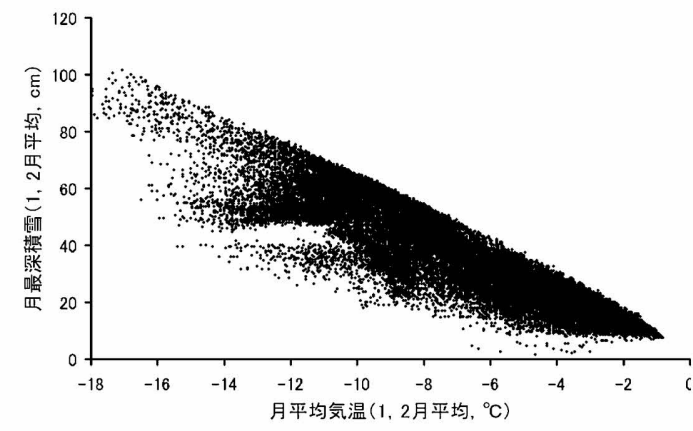

図 1 メッシュ気候值 2000 から $R_{\mathrm{av}}<8(\mathrm{~kg})$ の条件で 抽出された「しもざらめ雪地域」 37377 地点の 1,2 月平均の月平均気温と月最深積雪の関係.

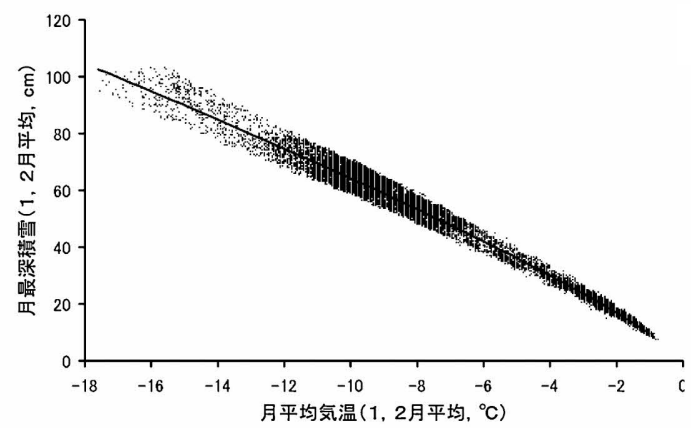

図 $2 R_{\mathrm{av}}=8$ の境界の值と考えられる $9>R_{\mathrm{av}}>7$ を満 たす地点の 1,2 月平均の月平均気温之月最深積 雪の関係と最適曲線.

そこでこの境界を求めることを考える。この場 合の境界は $R_{\mathrm{av}}=8$ であるから，境界付近と考えら れる $7<R_{\mathrm{av}}<9$ を満たす地点を抽出して図 1 上同 じ座標でプロットしたものが図 2 である，值が図 1 の境界付近に分布していることから，確かに境 界を構成する地点であるとがわわかる。そそこで, 境界をこれらの点の近似曲線と考えて，それを求 めると次の式で表される近似曲線が得られる.

$$
H_{\mathrm{J}, \mathrm{F}}=9.5\left|T_{\mathrm{J}, \mathrm{F}}\right|^{0.83}
$$

ここで， $H_{\mathrm{J}, \mathrm{F}}, T_{\mathrm{J}, \mathrm{F}}$ はそれぞれ 1,2 月平均の月 最深積雪 $(\mathrm{cm})$ 上月平均気温 $\left({ }^{\circ} \mathrm{C}\right)$ である.

境界の式が式(3)であるから，「しもざらめ雪地 域」の条件は次の不等式で表されることになる.

$$
H_{\mathrm{J}, \mathrm{F}}<9.5\left|T_{\mathrm{J}, \mathrm{F}}\right|^{0.83}
$$


このように，3月の月最深積雪を用いなくても， 1,2 月の值のみで「しもざらめ雪地域」を区分す る条件を表すことができる。また，この式は 1,2 月の気候值を用いた平均的な積雪の温度勾配を反 映しているので，その意味するところむ明瞭であ る。ちなみに，境界の温度勾配 $G$ を求めてみる と, 式(3)を利用して下記の式が得られる。

$$
G=\left|T_{\mathrm{J}, \mathrm{F}}\right| / H_{\mathrm{J}, \mathrm{F}} \approx 0.11\left|T_{\mathrm{J}, \mathrm{F}}\right|^{0.17}
$$

この式は境界の温度勾配が気温によって变わる ことを表し, 式 (5) から $-1{ }^{\circ} \mathrm{C}$ では $0.11^{\circ} \mathrm{C} \mathrm{cm}^{-1}$, $-10^{\circ} \mathrm{C}$ では $0.16^{\circ} \mathrm{C} \mathrm{cm}^{-1}$ 上気温が低くなるにした がって，大きな温度勾配でないと「しむざらめ雪 地域」になれないことを表している。気温が低く なると，地面の凍結が起こり積雪接地面の温度が 下がるので，接地面を $0^{\circ} \mathrm{C}$ と考えて気温から求め る温度勾配に比べ実際の温度勾配は小さくなり， その分気温から算出される温度勾配の場合の条件 を大きくしなければならないことに対応してい る.あるいは，気温の高い「しもざらめ雪地域」で は温度勾配の条件を満たすために必然的に積雪深 が小さくなければならない結果，雪のしまり方が 弱いので, 積雪内部の水蒸気が移動し易く, しも ざらめ雪ができやすいということを反映している と考えることもできる（遠藤ら，1976）。どちらも， 低い気温の方が，大きな温度勾配を必要とするこ とを示唆していて，条件式の傾向と一致する.

なお，ここで得られた温度勾配は月最深積雪を
用いていることから，例えば秋田谷・遠藤 (1977) で 1 月の平均的な温度勾配が $0.21^{\circ} \mathrm{C} \mathrm{cm}^{-1}$ 以上を しもざらめ雪の発達する地域としているのに比べ 小さい值である。ただ，月最深積雪は月平均積雪 に比べ 1.5〜2 倍以上となること屯多いので，それ を考慮すると, 得られた温度勾配は妥当な範囲に あると考えられる.

さて次に，式(4)の形で表される区分条件の緩 和について検討することになるのだが，それは前 節でも述べたように境界 $R_{\mathrm{av}}=8$ を大きい方へ上 げて行くことに対応する。そこで，ここで行った ことと同様のことを $R_{\mathrm{av}}=9 \sim 11$ について行うと, それぞれの $R_{\mathrm{av}}$ に対して式 (4) に対応する緩和さ れた条件式が得られる。表 1 はそれらの一覧で, それぞれ $-1{ }^{\circ} \mathrm{C}$ と $-10^{\circ} \mathrm{C}$ に対応する温度勾配と合 わせて載せたものである。なお，表の最後の欄の 「しもざらめ年」の割合については, 結果のところ で触れることにする。

なお，最適曲線の近似式を求めるために，ここ ではデー夕数が多いメッシュ気候值を用いたが, 得られた結果を気象官署とアメダスのデータに適 用したところ，従来の式(1)，(2) での区分と 1，2 月の值だけの式(4)による区分とはほとんど一致 することが確かめられた。実際のデー夕において 屯置き換えが可能であることがわかったわけであ るが，それについてはここでは省略する。

\section{4.「しもざらめ雪地域」の定義の定量化} これまでの「しもざらめ雪地域」は，厳冬期に

表 1 異なる境界 $R_{\mathrm{av}}$ （平均ラム硬度， $\mathrm{kg}$ ）に対応した「しもざらめ雪地域」の区分条件 と温度勾配，及びその境界で区分した場合に推定される「しもざらめ年」の割合.

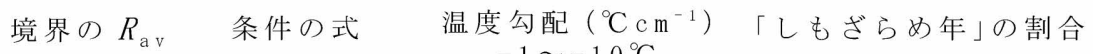

\begin{tabular}{lllll}
\hline 1. & $R_{\mathrm{av}}=8$ & $H_{\mathrm{J}, \mathrm{F}}<9.5\left|T_{\mathrm{J}, \mathrm{F}}\right|^{0.83}$ & $0.11 \sim 0.16$ & $>\sim 90 \%$ \\
2. & $R_{\mathrm{av}}=9$ & $H_{\mathrm{J}, \mathrm{F}}<10\left|T_{\mathrm{J}, \mathrm{F}}\right|^{0.83}$ & $0.10 \sim 0.15$ & $>\sim 80 \%$ \\
3. & $R_{\mathrm{av}}=10$ & $H_{\mathrm{J}, \mathrm{F}}<11\left|T_{\mathrm{J}, \mathrm{F}}\right|^{0.84}$ & $0.09 \sim 0.13$ & $>\sim 70 \%$ \\
4. & $R_{\mathrm{av}}=11$ & $H_{\mathrm{J}, \mathrm{F}}<12\left|T_{\mathrm{J}, \mathrm{F}}\right|^{0.84}$ & $0.08 \sim 0.12$ & $>\sim 60 \%$ \\
\hline
\end{tabular}

$H_{\mathrm{J}, \mathrm{F}}: 1,2$ 月平均の月平均気温 $\left({ }^{\circ} \mathrm{C}\right), T_{\mathrm{J}, \mathrm{F}}: 1,2$ 月平均の月最深積雪 $(\mathrm{c} \mathrm{m})$ 
しもざらめ雪が著しく発達する地域として定義さ れ，定量的な部分については先の区分条件 (1) (2) で示されてきた。そその結果，確かに「しもざらめ 雪地域」を定量的に抽出できるが，結果として得 られた地域がどのような地域なのかがわからず, 前に述べたように観測結果と比較して定量的な意 味づけを検討しなければならないということが生 じた。そこで，ここでは定義そのものの中で「し もざらめ雪地域」を定量的に表すことについて考 える.

秋田谷・遠藤（1982）でもそうであるが，調査 した年のすべての冬に彼らが定義した“しもざら め雪地域”之なった地域屯あれば，うち何年かは そこまでは発達しなかった地域むある。このよう にその年の冬の有り様によって，しもざらめ雪が 発達する年とそうでない年があることは容易に想 像できる。温度勾配が大きい地域は，ほぼ毎年し あざらめ雪が発達するだろうし，境界線上にある ような地域では，発達する年むそうでない年ああ るだろう。

そこで,「しもざらめ雪地域」を定量的に定義す る一つの方法として，気候的な期間，例えば平年 值で一般的な 30 年の間のうち，何冬期で秋田 谷・遠藤 (1982) が言う“しもざらめ雪地域”之 なり得るかを一つの尺度とすることが考えられ る.ここでは，そのような年を「しもざらめ年」 と呼び，以下では寒冷な割に雪の少ない地点につ いて，過去の気象データから「しもざらめ年」の 年数を推定し, その頻度（30 年間における年数割 合）之前節の区分条件との関係から，定量的な定 義を検討することにする。

\section{5. 過去の気象データからしもざらめ雪の 発達を推定する方法}

過去のデー夕にしもざらめ雪の発達が記録され ているわけではない，そこで，ここでは和泉・秋 田谷（1986）が本州におけるしもざらめ雪の分布 の研究で行ったように, 過去の気象データからし むざらめ雪の発達した年を推定することにした。 発達の評価は彼らと同じく基本的には秋田谷・遠 藤（1982）の式(1)，(2)を使うが，以下に述べるよ うに期間の取り方などに修正を加えた。

気象デー夕を調べて見ると，しもざらめ雪が発
達する地域は一般に雪が少ないので, 積雪の中断 や 2 月末日の積雪が無いことが多い。一方, しも ざらめ雪の発達には, 積雪内に温度勾配が存在す る状態で一定の時間経過が必要である。あし，積 雪の中断があると発達に必要な時間が不足して発 達できない。また，2月末日という特定な日に積 雪が無く，し屯ざらめ雪の発達を評価できないと いうのも問題である. 例えば, その数日前まで積 雪があり，しもざらめ雪が発達していた可能性を 否定できないからである，積雪の継続について は, 和泉・秋田谷 (1986) でも推定の過程で 2 月 中に中断がある冬は除外するなどの条件を設定し ているが，ここでは 1 月における積雪の中断にも 配慮して, 次のような条件を満たす時にしもざら め雪の発達を評価することにした。

まず 2 月末と言う点は，厳冬期の末，まだ融雪 が始まらない前の, しむざらめ雪が充分に発達し たと考えられる時期に評価するということである から，少し緩和して図 3 に示すように，2 月 15 日 から末日までに範囲を広げる。また，積雪の中断 については，上記の期間の積雪が存在する日から 遡って 1 ヶ月以上積雪が継続した場合にのみ評価 を行うことにする (図 3).ただし，1月 1 日より前 には遡らずに，そこまで積雪がある時は 1 月 1 日 から計算する，そうして．式(1)の $H_{1}$ には継続期間 の平均積雪, $T$ もその間の平均気温, $H_{2}$ は継続最 終日（2 月末に積雪があれば 2 月末）の積雪深とし た。このようにすると, 㛜冬期の最低でも一ヶ月 間継続した積雪について，その間の温度勾配を反 映した評価ができることになる。ただし，最終日 の積雪が $1,2 \mathrm{~cm}$ と小さいと, べき乗の数が小さ いとは言え，この項が効き過ぎるきらいがある. そこで，最終日積雪が $5 \mathrm{~cm}$ 以下の場合は，2 月 15 日から消日までで最も深い時の積雪を $H_{2}$ とした。

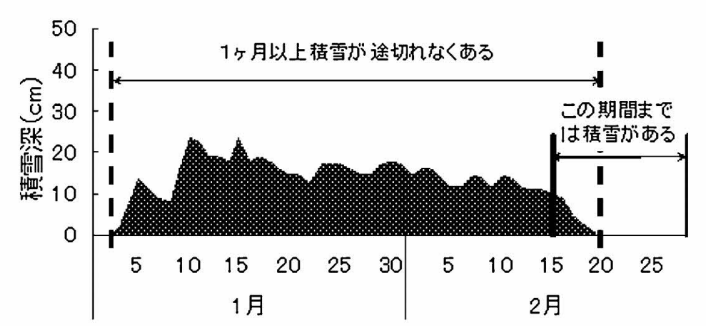

図 3 計算の前提となる期間の条件. 
6.「しもざらめ年」となった年数の割合 30 年という長い期間の評価を行うので, 対象之 なる地点を気象官署とし，これまでの基準で「し あざらめ雪地域」とされていた地点及び境界付近 之考元られる地点, 合わせて 21 の気象官署を対 象とした，対象期間は現在の平年値期間である 1971 年から 2000 年の冬，1，2 月である。前節で 述べた方法で，各地点の各年毎の積雪の継続状況 を調べ，しもざらめ雪の発達具合を推定した。そ の結果を表 2 に平年值（気象庁，2001）の平均気 温の低い順に掲げた。

前にも述べたように，しもざらめ雪が発達する 地域は一般に積雪が少ない地域なので，厳冬期に 1 ヶ月以上積雪が連続するという条件を満たさな いことも多い，特に気温が高めになると，積雪深 がより小さくなければ，しもざらめ雪が発達する のに必要な大きな温度勾配とならない。そうなる と，ますます積雪が連続しないことが多くなる。 例えば諏訪はその典型的な例で, 30 年の間に一冬 も先の計算の前提となる条件（積雪が 1 ヶ月以上
継続）を満たさなかった地点である。阿蘇山，八 戸，江差などに比べて温度勾配は大きく，「しもざ らめ年」の割合が高くなる可能性があるにもかか わらずゼロとなったのは，積雪深が小さいため計 算できる冬が無かったという事情が反映した結果 である。その他の地点む気温が高めになると, 計 算対象にならない年が増え，計算した年に対する

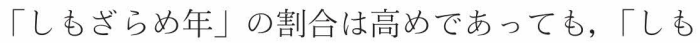
ざらめ年」の絶対数は少なく, 10 年にも満たない ことが多い，気温の高い地域でのしもざらめ雪の 発達の評価については，上記の難しさがある点に 注意する必要がある。

\section{7.「しもざらめ年」の頻度と気候区分条件 の関係}

図 4 は先に求めた表 1 の各境界条件のグラフに 「しもざらめ年」を推定した気象官署の值を載せ たむのである. 地名の後の括弧の中の数字は, 先 頭から表 2 のしもざらめ雪が発達したと推定され た年数, 発達しなかったと推定された年数であ

表 2 気象官署 21 地点の気候値としもざらめ雪が発達したと推定された年数とその割合

\begin{tabular}{|c|c|c|c|c|c|c|c|}
\hline 地点名 & $\begin{array}{c}\text { 月平均気温 } \\
(1,2 \text { 月平均 }) \\
\left({ }^{\circ} \mathrm{C}\right) \\
\mathrm{A} \\
\end{array}$ & $\begin{array}{c}\text { 月最深積雪 } \\
(1,2 \text { 月平均 }) \\
(\mathrm{cm}) \\
\mathrm{B}\end{array}$ & 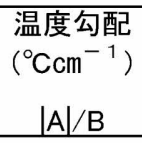 & $\begin{array}{c}\text { しもざらめ雪 } \\
\text { の発達した } \\
\text { 推定年数 } \\
\text { C } \\
\end{array}$ & $\begin{array}{c}\text { しもざらめ雪が } \\
\text { 発達しなかっ } \\
\text { た推定年数 } \\
\text { D } \\
\end{array}$ & 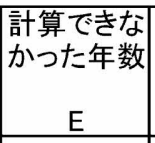 & \begin{tabular}{|c|} 
しもざらめ年 \\
の割合 \\
$(\%)$ \\
$\mathrm{C} /(\mathrm{C}+\mathrm{D}) \times 100$ \\
\end{tabular} \\
\hline 旭川 & -7.5 & 85 & 0.09 & 3 & 27 & 0 & \begin{tabular}{|l|}
10 \\
\end{tabular} \\
\hline 帯広 & -7.3 & 51 & 0.14 & 23 & 4 & 3 & 85 \\
\hline 雄武 & -7.0 & 62 & 0.11 & 18 & 12 & 0 & 60 \\
\hline 網走 & -6.3 & 47 & 0.13 & 22 & 8 & 0 & 73 \\
\hline 紋別 & -6.2 & 52 & 0.12 & 23 & 7 & 0 & 77 \\
\hline 釧路 & -5.3 & 29 & 0.19 & 19 & 1 & 10 & 95 \\
\hline 稚内 & -5.1 & 72 & 0.07 & 6 & 24 & 0 & 20 \\
\hline 広尾 & -4.8 & 71 & 0.07 & 7 & 22 & 1 & 24 \\
\hline 根室 & -4.4 & 25 & 0.18 & 18 & 2 & 10 & 90 \\
\hline 奥日光 & -4.2 & 32 & 0.13 & 13 & 4 & 13 & 76 \\
\hline 苫小牧 & -3.9 & 22 & 0.18 & 14 & 0 & 16 & 100 \\
\hline 軽井沢 & -3.5 & 22 & 0.16 & 11 & 1 & 18 & 92 \\
\hline 浦河 & -2.8 & 18 & 0.16 & 9 & 2 & 19 & 82 \\
\hline 函館 & -2.7 & 38 & 0.07 & 9 & 12 & 9 & 43 \\
\hline 室蘭 & -2.2 & 20 & 0.11 & 10 & 4 & 16 & 71 \\
\hline 盛岡 & -1.9 & 30 & 0.06 & 4 & 10 & 16 & 29 \\
\hline 高山 & -1.5 & 41 & 0.04 & 8 & 11 & 11 & 42 \\
\hline 諏訪 & -1.3 & 14 & 0.09 & 0 & 0 & 30 & 0 \\
\hline 阿蘇山 & -1.2 & 17 & 0.07 & 2 & 1 & 27 & 67 \\
\hline 八戸 & -1.1 & 23 & 0.05 & 2 & 4 & 24 & 33 \\
\hline 江差 & -1.0 & 30 & 0.03 & 6 & 14 & 10 & 30 \\
\hline
\end{tabular}




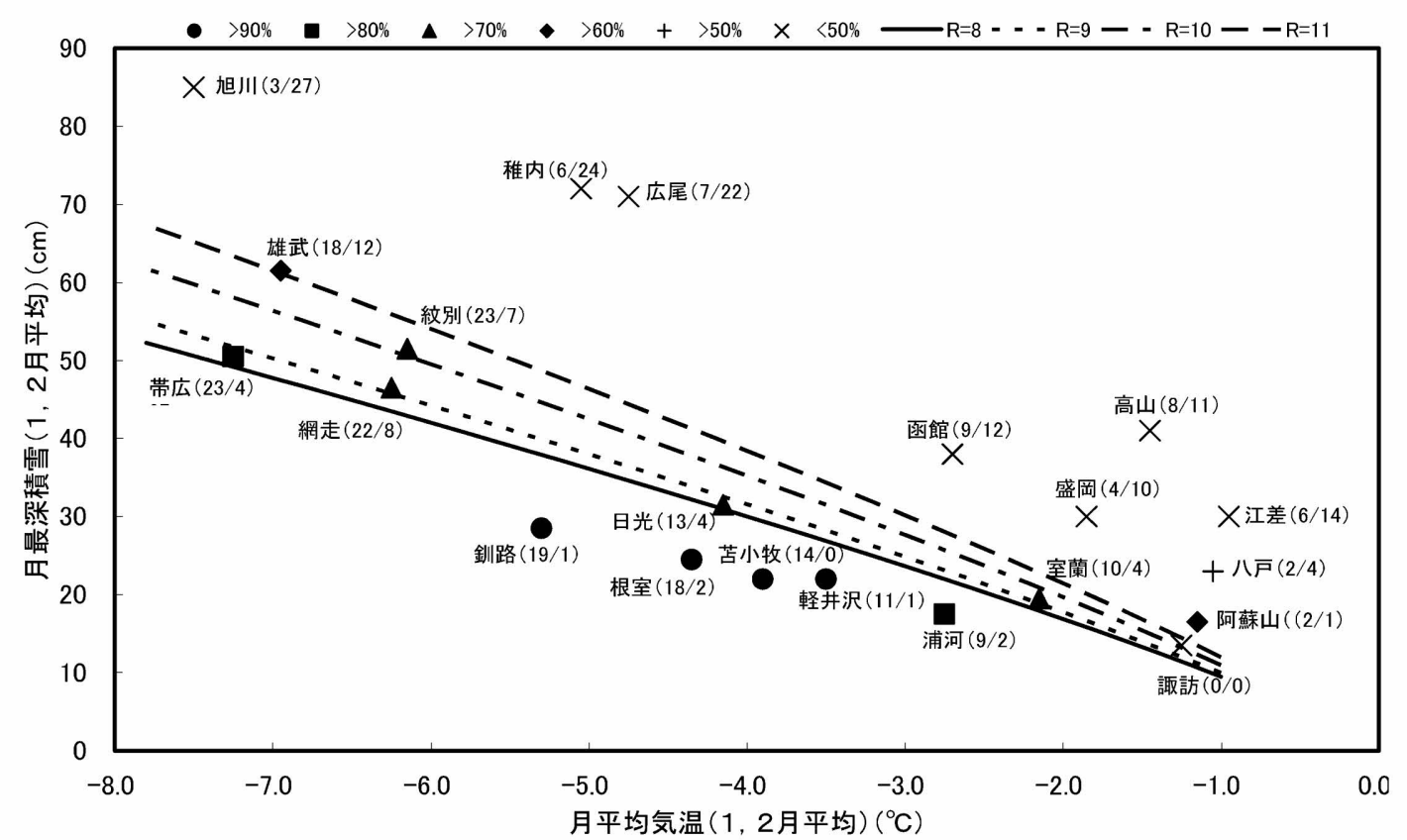

図 4 気象官署 21 地点の 1,2 月平均の月平均気温と月最深積雪との関係と, $R_{\mathrm{av}}=8,9,10,11$ に対応する境 界を表す曲線. 地点名の記号は，「しもざらめ年」の割合（\%) を階級別に表し，（）内は左から順に 推定された「しもざらめ年」と非「しもざらめ年」を表す。

る.これらの和が評価の可能であった年数であ り, 30 からこれらの和を引いた年数は計算できな かった年数となる.

地名に対応した異なる記号は「しもざらめ年」 の頻度割合（\%) を階級別に表している。ただし， この割合は表 2 の最後の欄に掲げた，計算できな い年を除外して求めた割合, すなわち計算可能で あった年に対する「し屯ざらめ年」の割合である。 境界の線は一番下が，これまでの基準 $R_{\mathrm{av}}<8$ に 対応したもので, 上に行く従い表 1 の緩和された 条件, すなわちより小さい温度勾配（より大きい $R_{\mathrm{av}}$ ）に対応した境界線となっている。

図を見ると，これまでの基準の「しもざらめ雪地 域」, すなわち一番下の曲線より下の領域は, $80 \%$ 台では $82 \%$ の浦河を含んでいるが，85\%の帯広を 含まないのに対して，90\%台のすべての地点を含 んでいることから，ほぼ 9 割方「しもざらめ年」と なる地域を区分する条件であったことがわかる. その意味では, 前に述べたように, これまでの条件 が「しもざらめ雪地域」をより限定的に厳しく区分 していることを改めて確認できたと言える.

同様にして寒い地域の計算対象年数の多い地域
に注目して検討すると, 対象の点が少なく荒い推 定ではあるが $R_{\mathrm{av}}<9$ はおよう $80 \%, R_{\mathrm{av}}<10$ は $70 \%, R_{\mathrm{av}}<11$ は $60 \%$ のしむざらめ年」の頻度 割合に対応する区分条件であることがわかる，表 1 の最後の欄はその結果を載せたものである.

$1^{\circ} \mathrm{C}$ 付近の気温の高い領域では, しもざらめ雪が 発達するには積雪が小さすぎて，1 ヶ月以上にわ たって積雪が継続する年はまれであり, 境界線よ り下にあっても, 諏訪のようにゼロと表示するし かない地点や，わずか 3 年しか計算できず，その うち 2 冬期が「しもざらめ年」となったために 60\%台となる阿蘇山など, 必ずしも先の検討結果 と整合しない事情屯かいま見られ, 先に述べたよ うに, 高い気温帯では区分条件の難しさを反映し た結果となっている.

\section{8. 新しい気候区分とメッシュ気候値 2000 に基づく気候図}

これまで述べてきたように，「しもざらめ雪地 域」を平年值算出期間 30 年の間における「しもざ らめ年」の頻度 (年数の割合) で定義し, その割 合に応じた区分条件を見出すことができた。この 


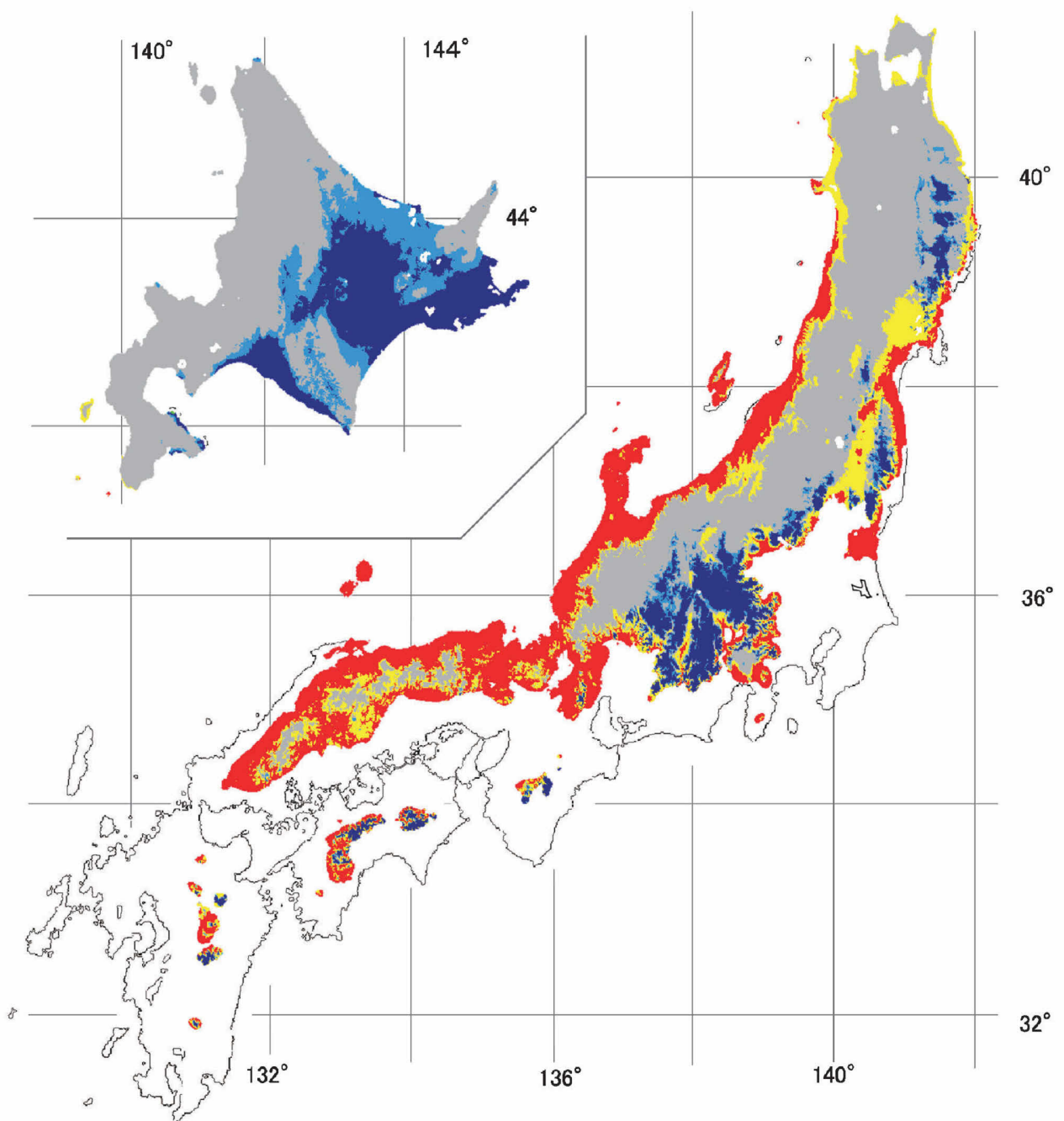

\begin{tabular}{|c|c|c|c|}
\hline 区 分 & \multicolumn{2}{|r|}{ 気候条件 } & 積雪の特徵 \\
\hline 湿り雪地域 & \multicolumn{2}{|l|}{$T_{3} \geqq 0.3^{\circ} \mathrm{C}$} & 蕨冬期でも積雪が水を含を. 積雪内にざらめ雪が多い. \\
\hline 中間地域 & \multicolumn{2}{|c|}{$T_{\mathrm{s}}=-1.0 \sim 0.3^{\circ} \mathrm{C}$} & 湿り雪地域と乾き雪地域の中閒的性格の積雪. \\
\hline 乾きき雪地域 & $T_{3}<-1.0^{\circ} \mathrm{C}$ & $H_{b, P} \geqq 12\left|T_{J, F}\right|^{\mid 84}$ & 厳冬期は雪が乾いている．多雪時しまり雪が発達する。 \\
\hline \multirow{2}{*}{ 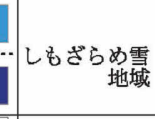 } & \multirow{2}{*}{$T_{3}<-1.0^{\circ} \mathrm{C}$} & 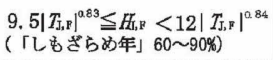 & \multirow{2}{*}{ 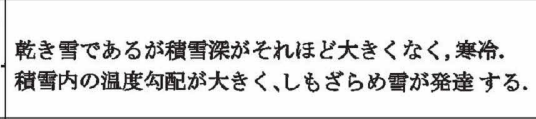 } \\
\hline & & 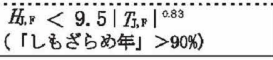 & \\
\hline 非積䋍地域 & \multicolumn{2}{|l|}{$H<10 \mathrm{~cm}$} & 冬期のいずれの月も月最深積雪がが $10 \mathrm{~cm}$ 未満. \\
\hline
\end{tabular}

図 5 メッシュ気候值 2000 （気象庁，2002）に区分条件（表）を適用して作成した厳冬期の積雪 の質的特徵に基づく日本の積雪地域の気候区分図.

新しい「しもざらめ雪地域」の定義を採用し，他 のこれまでの区分と合わせ，かつ新しい気候值 「メッシュ気候值 2000」」(気象庁, 2002) に基づい た日本の積雪地域の積雪の質の気候図を図 5 に示
す。「しむざらめ年」の頻度をどの程度に設定する かは，必要とすることがらによっても変わってく ると思われるので，図には「し屯ざらめ年」の年 数割合が $6 \sim 9$ 割と 9 割以上の地域を分けて表現 
した。すなわち，気候的に「しもざらめ雪地域」 を指すには，6 割以上が最大限に緩和した条件之 考え，さらにそれ以上を二つに分けたものであ る. 冬期いずれかの月の月最深積雪が $10 \mathrm{~cm}$ 以上 の地点を積雪地域として区分対象とし，各区分条 件と簡単に記した積雪の特徴は, 図中の表に示し たと抢りである。 区分の基本的な定義については 変更がないので，その詳細な表現については前著 （石坂，1995，1996）を参照されたい.

図 5 に示された分布は，対象域が拡大したこ 之, 「しむざらめ雪地域」が増えた分「乾き雪地 域」が減ったということはあるが，そ机以外の気 候区分については変更がないので，基本的には旧 メッシュ気候值を用いたものと大きくは変わって いない。「湿り雪地域」と「乾き雪地域」の境界は 北緯 $40^{\circ}$ 付近にあり, 以南の平野は「湿り雪地域」 となり，「乾き雪地域」はある程度標高がないと存 在しない，図 6 はそ机を「湿り雪地域」の緯度之 標高之の関係でみたものである. 図 6 で示されて いる「湿り雪地域」の分布の高緯度, 高標高側に 「乾き雪地域」と「しもざらめ雪地域」が, 低緯度, 低標高側に「非積雪地域」が，それぞれ部分的に 重なりながら存在していることになる。旧メッ シュ気候值（積雪）（気象庁，1996）では対象外で あり，今回新たに加わった対象域，紀伊，四国， 九州については，北緯 $34^{\circ}$ 以南から標高ゼ口付近 の「湿り雪地域」が無くなることから，これらの 平野部はすべて「非積雪地域」であることがわか る。 そのことは図 5 の気候図からも明瞭で，これ らの地域では, 積雪地域はごく狭い山岳地域に限 られている，ただ，その狭い中にこの後述べるよ うに「しもざらめ雪地域」が存在していることが 注目される。

「しもざらめ雪地域」は，道東，北上高地及び盆 地，佐久盆地を中心とした長野県の中央部から南 部山岳（この部分は新たに加わった部分が多い） にかけて存在している（図5)。特に道東では緩和 した場合の面積（明るい青色）が大きくなってい る.これは図 4 のグラフで「しもざらめ年」の頻 度が 6 割以上と 9 割以上に対応する境界の二曲線 が，低温域側で次第に離れて両者の間隔が広く なっていることと関係している。すなわち，道東 の地点の多くがこの広がった間隔の間に入るので

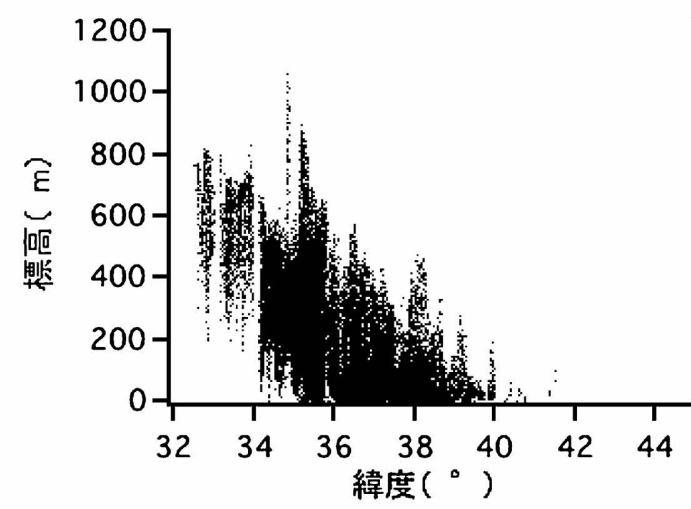

図 6 「湿り雪地域」に属する地点の緯度と標高の関係,

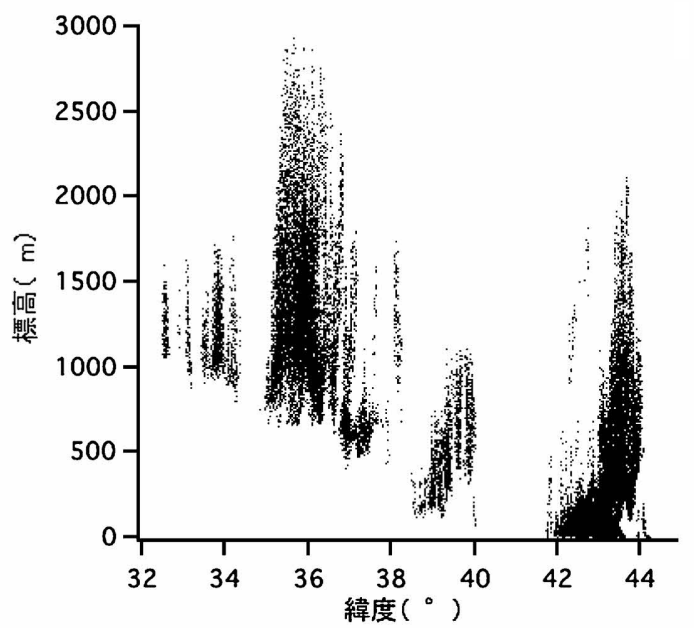

図 7 「しむざらめ雪地域」に属する地点の緯度と標高 の関係.

ある.

さらに，上述したように，紀伊，四国，九州の 山地のごく一部に「しもざらめ雪地域」が見られ る. 図 7 に「しむざらめ雪地域」の緯度之標高の 関係を示したが，これらの地域の「しもざらめ雪 地域」は，拉よそ $1000 \mathrm{~m}$ からそれ以上に分布し ていることがわかる。これら山域より北にある中 国山地になく，より南の山域にあることは興味深 い. 九州，四国の山域の方が中国地方のそれより 標高が高いこともあるが，中国地方では標高の高 い所では寒冷ではあっても一般的に積雪む多いこ とが一つの要因と考えられる。ただ，メッシュ気 候値はあくまであ推定値であり, 特に高標高域で の誤差は大きいと考えられるので, 実際について 
はそれぞれ検証される必要がある。とは言え，紀 伊，四国，九州の「しもざらめ雪地域」は北海道 などのそれと比べ相対的に気温が高く積雪深む小 さいので，前に述べたように積雪の継続が困難な 地域であり, 検証自体が難しいことも否めない。 ただ，図 5 の気候図でも示されている四国の剣山 については，和泉・秋田谷 (1986) がその存在の 可能性に触れていることから，ここで得られた推 定は大きく違ってはいないと思われる.

次に, 日本全体の積雪地域の分布が明らかに なったので, 各積雪区分の占める面積比率を求め てみる。メッシュ数は㛜密ではないがほぼ面積に 対応していると考えられるので，メッシュ数の割 合で占有面積を算出してみると，積雪地域がおよ そ 65\% に対して非積雪地域は約 35\% となり，日 本の国土のおよそ三分の二を積雪地域が占めてい る。積雪地域の中での割合では,「湿り雪地域」は $18 \%$ あまり，「中間地域」 $10 \%$ ，残る約 $72 \%$ を 「乾き雪地域」と「しもざらめ雪地域」が占めてい る.「しもざらめ雪地域」をここで示した年数割合 が 6 割以上という緩和した条件で区分すると「し むざらめ雪地域」，「乾き雪地域」が積雪地域の中 で占める割合は，それぞれ $23 \%$ と $49 \%$ となる。 ちなみに従来の区分に近い「しもざらめ年」頻度 9 割以上の場合は，それぞれ $15 \%$ と $57 \%$ となり, 6 割以上まで緩和することによって「しもざらめ 雪地域」の面積が 1.5 倍となることがわかる.

その他，本気候図は数值情報を背景としている ので，気候的あるいは地理的な情報を利用してさ まざまことがわかるが，それについては改めて別 に論じることにしたい.

\section{9. おわりに}

日本の積雪地域の厳冬期の積雪の質的特徵に基 づいた気候区分概念の一つである「しもざらめ雪 地域」の定義および気候条件について再検討した。 定義の気候的意味づけを明確にするため，しもざ らめ雪の発達する地域之その境界付近の気象官署 の 30 年間の冬期について，しあざらめ雪が発達す る年である「しもざらめ年」の割合を推定した。そ して，その結果と区分条件とを比較することに よって，「しもざらめ雪地域」を気候的な期間（30 年間)での「しもざらめ年」の一定以上の年数割合
で定義して，それに対応する区分条件を提案する ことができた。 区分条件は，気候的な雪中温度勾 配を反映したもので，「しもざらめ雪」の発達と関 係する指標としては適切な表現と言える.

そして, 新たな「しあざらめ雪地域」の定義と従 来の気候区分とを合わせて，それらを最新のメッ シュ気候值であるメッシュ気候值 2000 (気象庁, 2002）に適用して，積雪の質の気候図を作成した。 積雪の量の気候図は既に, 年最深積雪の分布図 (気 象庁，2003）としてあるので，この両者によって， 日本の積雪の堆積環境を表す質と量の両方の気候 困が得られたことになる。これらの質と量とが全 く無関係ではないことは，既に筆者が論じた気温， 降水量，積雪深の関係（石坂，2006a，2007）や気 候变動に対する応答 (Ishizaka, 2004) の中に反映 されていることからもわかる。むちろん，変化の 激しい雪を筆者が提案する比較的単純な区分だけ で表すことは充分ではないと思われるが，雪国の 生活，防災，雪と動植物の関係などの自然との関 わりには，積雪の量と質の画面が反映していると 考えられるので, それらのことを検討する時, こ こで提案した気候図が役に立つはずである。

\section{謝辞}

本研究過程の中で行われた各気象官署の 30 年 間の毎年 1, 2 月の毎日の積雪データから, 積雪の 中断の有無を調べる作業は大変骨の折れるもので あり，これについては防災科学技術研究所雪水防 災研究センターの三浦美枝子氏に負うところ大で あった。また，気候図の作成の過程では，旧メッ シュ気候值と同様，新しいメッシュ気候值につい てむデータベース化し検索の利便性を高めたが, それについては富山コンピュー夕専門学校の小林 敏一氏にご指導いただいた。また。論文作成にあ たっては，二人のレフリーおよび編集担当者から 有益な助言をいただき論文に反映させることがで きた。ここに記して感謝申し上げる.

なお, 本研究は科学研究費補助金（課題番号 18500787）によるものである.

\section{文献}

秋田谷英次 ·遠藤八十一, 1977 : 石狩 - 空知地方の積雪 調査. 低温科学, 35, 105-115. 
秋田谷英次・遠藤八十一, 1980 : 北海道平野における厳 冬期の積雪特性. 低温科学, 39, 55-61.

秋田谷英次 - 遠藤八十一, 1982 : 北海道内平地に扮ける 積雪特性. 昭和 54-56 年北海道大学特定研究経費研究 成果報告書, 1-17.

遠藤八十一 一秋田谷英次 - 高橋 徹 - 和泉 薰, 1976 ： 石狩・勇払平野に扔ける積雪の特性. 低温科学, 34 , 133-145.

石坂雅昭, 1995 : メッシュ気候值から推定した日本の雪 質分布. 雪水， 57，23-34.

石坂雅昭, 1996 : 日本の冬の気候之積雪の地域性. 雪 水, $58,4,329-338$.

Ishizaka, M.,1998: New categories for the climatic division of snowy areas in Japan. Ann. Glaciol., 26, 131-137.

Ishizaka M.,2004 : Climatic response of snow depth to recent warmer winter seasons in heavysnowfall areas in Japan. Ann. Glaciol., 38, 299-304.
石坂雅昭, $2006 \mathrm{a}$ : 温暖な積雪地域「湿り雪地域」におけ る月最深積雪の平年值の上限について. 雪水, 68,179 $-190$.

石坂雅昭, 2006b : メッシュ気候值 2000 における「しむ ざらめ雪地域」の気候条件について, 寒地技術論文・ 報告集， $22 ， 12-15$.

石坂雅昭, 2007 : 日本の積雪地域の月平年値に掞ける積 雪・気温・降水量間の関係。雪水，69，591-599.

和泉 薰・秋田谷英次, 1986 : 本州におけるしもざらめ 雪の分布. 雪水, 48, 199-206.

気象庁, 1996 : メッシュ統計值 (旧メッシュ気候值). 気 象庁観測平年值 (CD-ROM), 気象業務支援センター. 気象庁, 2001 : 平年值 統計期間 1971 2000 年 (CDROM). (財)気象業務支援センター.

気象庁，2002：メッシュ気候值 2000 統計期間 1971〜 2000 年 (CD-ROM). (財)気象業務支援センター.

気象庁，2003: 日本気候図 2000 年版 統計期間 1971 2000 年 (CD-ROM). (財)気象業務支援センター.

\title{
Reassessment of climatic conditions in "depth-hoar region" and new map for climatic division of snow-covered areas in Japan based on the new conditions
}

\author{
Masaaki IsHIZAKA ${ }^{1)}$ \\ 1) Snow and Ice Research Center, National Research Institute for \\ Earth Science and Disaster Prevention, \\ Suyoshi, Nagaoka, 940-0821
}

\begin{abstract}
The depth-hoar region is one of the categories introduced by the author for the climatic division of the snow-covered areas in Japan based on the snow-cover character in mid-winter. In this study, to clarify the climatic implications of the definition of the depth-hoar region, we determined the number of winter seasons in which depth hoar developed to a significant level that was distinguishable as the "depth-hoar region." Data were obtained from 21 official meteorological observation sites for the 30 years from 1971 to 2000, and were analyzed using the diagnostic formula introduced by Akitaya and Endo (1982). As a result, we could derive a new climatic condition that distinguishes the depth-hoar region from the others and that corresponds to a new definition, representing the frequency of "depth hoar developing significantly in the winter season" over the 30 years.

We also present a new digital cartographic map for climatic division that reflects the new definition for the depth-hoar region, using Mesh Climatic Data 2000, newly developed mesh climatic data published by Japan Meteorological Agency.
\end{abstract}

（2007 年 9 月 5 日受付, 2007 年 11 月 13 日改稿受付, 2007 年 11 月 19 日再改稿受付, 2007 年 11 月 20 日受理 討論期限 2008 年 7 月 15 日） 